\title{
Water quality and health in a Sahelian semi-arid urban context: an integrated geographical approach in Nouakchott, Mauritania
}

\author{
Doulo Traoré ${ }^{1,2,3}$, Ibrahima Sy ${ }^{2,4,5}$, Jürg Utzinger ${ }^{4,5}$, Michael Epprecht $^{6}$, Ives M. Kengne ${ }^{7}$, Baidy \\ Lô ${ }^{8}$, Peter Odermatt ${ }^{4,5}$, Ousmane Faye ${ }^{1}$, Guéladio Cissé ${ }^{4,5}$, Marcel Tanner ${ }^{4,5}$ \\ ${ }^{1}$ Department of Geography, University Cheikh Anta Diop of Dakar, Dakar, Senegal; ${ }^{2}$ Institut National de \\ Recherches en Santé Publique, Nouakchott, Mauritania; ${ }^{3}$ Centre Suisse de Recherches Scientifiques en Côte \\ d'Ivoire, Abidjan, Côte d'Ivoire; ${ }^{4}$ Department of Epidemiology and Public Health, Swiss Tropical and Public \\ Health Institute, Basel, Switzerland; ${ }^{5}$ University of Basel, Basel, Switzerland; ${ }^{6}$ Centre for Development and \\ Environment, University of Bern, Bern, Switzerland; ${ }^{7}$ Department of Natural Sciences, University of Yaoundé, \\ Yaoundé, Cameroon; ${ }^{8}$ General Inspection of Health, Ministry of Health, Nouakchott, Mauritania
}

\begin{abstract}
Access to sufficient quantities of safe drinking water is a human right. Moreover, access to clean water is of public health relevance, particularly in semi-arid and Sahelian cities due to the risks of water contamination and transmission of water-borne diseases. We conducted a study in Nouakchott, the capital of Mauritania, to deepen the understanding of diarrhoeal incidence in space and time. We used an integrated geographical approach, combining socio-environmental, microbiological and epidemiological data from various sources, including spatially explicit surveys, laboratory analysis of water samples and reported diarrhoeal episodes. A geospatial technique was applied to determine the environmental and microbiological risk factors that govern diarrhoeal transmission. Statistical and cartographic analyses revealed concentration of unimproved sources of drinking water in the most densely populated areas of the city, coupled with a daily water allocation below the recommended standard of 201 per person. Bacteriological analysis indicated that $93 \%$ of the non-piped water sources supplied at water points were contaminated with 10-80 coliform bacteria per 100 ml. Diarrhoea was the second most important disease reported at health centres, accounting for $12.8 \%$ of health care service consultations on average. Diarrhoeal episodes were concentrated in municipalities with the largest number of contaminated water sources. Environmental factors (e.g. lack of improved water sources) and bacteriological aspects (e.g. water contamination with coliform bacteria) are the main drivers explaining the spatio-temporal distribution of diarrhoea. We conclude that integrating environmental, microbiological and epidemiological variables with statistical regression models facilitates risk profiling of diarrhoeal diseases. Modes of water supply and water contamination were the main drivers of diarrhoea in this semi-arid urban context of Nouakchott, and hence require a strategy to improve water quality at the various levels of the supply chain.
\end{abstract}

Keywords: water, quality, contamination, microbiological analysis, socio-environmental data, risk profiling, diarrhoea, Mauritania.

\section{Introduction}

The health status of a population is dependent on the availability of water in sufficient quantity and at good quality, especially in urban areas (Tessier, 1991). Access to clean water is a human right and is an essential determinant for good health, promoting physical and social well-being (Kjellstrom et al., 2007). The recognition of these issues made the United Nations (UN)

Ibrahima Sy

Department of Epidemiology and Public Health

Swiss Tropical and Public Health Institute

P.O. Box, CH-4002 Basel, Switzerland

Tel. +41 61 284-8111; Fax +41 61 284-8105

E-mail: ibrahima.sy@unibas.ch embark on the objective of halving the number of people with no access to safe water by 2015 with data from 1990 taken as the benchmark, and this goal is likely to be met (http://www.unmillenniumproject.org/ goals/index.htm). However, many cities still struggle to meet the needs of adequate supply of potable water for their people. The most recent estimates by the Joint Monitoring Programme (JMP) suggest that about 1.1 billion people lack access to safe potable water, 300 million of whom live in Africa (WHO-UN-Habitat, 2010; UNICEF-WHO, 2012).

An important factor explaining the recent decline of infant and child mortality is associated with the implementation of water supply programmes (Prüss-Üstün et al., 2008; Lozano et al., 2012). An adequate supply of quality water reduces the risk of contamination (faecal 
hazards) and effectively protects human health (Dos Santos and Legrand, 2007). In African urban areas, difficulties concerning access to potable water are associated with infectious diseases, such as diarrhoea, cholera and typhoid (Sy, 2006; Bartram and Cairncross, 2010). Diseases related to contaminated water affect an estimated 2.3 billion people and are responsible for $60 \%$ of child mortality (Briscoe et al., 1986; Tumwine et al., 2002). Among these diseases, diarrhoea occupies a high rank with approximately 4 billion episodes of illness and 1.8 million deaths every year. More than $90 \%$ of the global burden is concentrated in children below the age of 5 years, mostly in developing countries (Fewtrell et al., 2005; UNICEF-WHO, 2009; Lozano et al., 2012; Murray et al., 2012).

The spatio-temporal dynamics of water-borne diseases in cities are often governed by the geography of water supply (Vaguet, 1986; Sy, 2006). Hence, it is essential to simultaneously study the distribution of gastro-intestinal infections and the spatial heterogeneity of water quality and quantity. Geospatial tools and techniques, such as geographical information system (GIS), global positioning system (GPS), remote sensing and geostatistical analysis lend themselves for this endeavour (Bergquist and Rinaldi, 2010; Utzinger et al., 2011a).

In Nouakchott, the capital of Mauritania, transmission of diarrhoeal diseases is linked to the quality and quantity of available water through a diversity of proximal and distal risk factors (Gagneux et al., 1999; Sy et al., 2011). Subject to rapid urban growth in a context of difficulties in planning the water supply network, Nouakchott has a chronic shortage of potable water, which affects particularly the peripheral, underserved and marginalised communities. Indeed, less than a third of households have an improved source of supply (e.g. individual tap, public tap and neighbour tap) of drinkable water, whereas most of the people resort to unimproved water sources, such as tankers, truck water retailers and unprotected wells (ONS, 2007). In Nouakchott, access to improved drinking water sources is one of the lowest among the major cities in Mauritania (Ould Samba and Perrin, 2008). Additionally, there is unequal distribution of water, and hence a single mode of supply is not sufficient to adequately satisfy the water needs for all households. As diarrhoeal morbidity is closely linked to the nature of the water supply sources, we developed an integrated geographical approach combining various data sources that allowed for a spatially explicit analysis of the impact of water quality on population health in Nouakchott.

\section{Materials and methods}

\section{Study area}

The study was carried out in the district of Nouakchott, the administrative capital of Mauritania. The urban population was estimated at 850,000 inhabitants in 2009 (ONS, 2009), unequally distributed among the nine municipalities aggregated under the Nouakchott Urban Community (NUC).

\section{Data sources}

Socio-environmental, microbiological and epidemiological data were compiled and geo-referenced using various sources (e.g. digital map data, surveys, studies and reports). The data were explored for a series of indicators, primarily collected at the municipality level, that were subsequently subjected to statistical analysis and cartographic representation.

\section{Digital maps}

The Digital Map Database of Nouakchott, readily available at a scale of 1:10,000 (Delegation of Planning Territory \& Regional Action, DATAR-Mauritania), was used as the background layer for disease mapping. This digital map became available in 2010 and is based on aerial photographs taken in 2007. Overall, 478 shots have been taken, covering an area of approximately $2,000 \mathrm{~km}^{2}$ in the form of a rectangular structure neighbouring the Atlantic Coast and measuring $65 \mathrm{~km}$ in length and $32 \mathrm{~km}$ in width. Data were imported into Arc GIS version 10 (ESRI; Redlands, USA). The map database was updated from Google Earth images. Field survey data were obtained using a hand-held GPS receiver (Garmin $76 \mathrm{Cx}$; Olathe, USA) in order to delineate the spatial extent of the city.

\section{Socio-environmental data}

Socio-environmental information considered here mainly pertains to indicators of various modes of potable water supply. Data were obtained from the Permanent Survey on Living Conditions of Households in Mauritania, conducted by the "Office National de Statistique" (ONS) in 2008-2009. It is a general operation of data collection conducted at the unit of the municipality throughout the national territory in two rounds. A total of 13,705 households were sampled, including indicators for the measurement of access, use and satisfaction of the population with regards to key basic social services. Information on access to potable water used in this article is presented 
at the unit of the municipality. Importantly, nearly half of the sampled households reside in Nouakchott. These quantitative data were supplemented by qualitative information from studies of the NUC pertaining to water distribution.

\section{Microbiological data}

Microbiological data were obtained from analyses conducted in Nouakchott in 2009 that assessed the impact of water quality on population health. Specifically, the study aimed at providing information on the degree of bacterial, chemical and parasitic contamination of water in order to determine the exposure levels of the local communities.

The study was conducted from June to August 2009 in the nine municipalities of Nouakchott. Water samples were collected at selected points along the distribution network and from 150 water points (water basins and public taps) in all municipalities for bacteriological, chemical and physical analyses. An assessment of the hygienic situation of the environment was done and the geographical coordinates of all sampled water points were collected by a hand-held GPS receiver. The bacteriological analysis is focused on coliform contamination to provide an indicator for the water supply quality in Nouakchott.

\section{Epidemiological data}

Epidemiological data consisted mainly of information on diarrhoeal diseases that were obtained from the health information system of the Regional Delegation for Health Action (RDHA) of Nouakchott. The data stem from a compilation of reports from health information records at health care centres. Data are readily available at the health district centre of the city, which lists aggregated number of cases from the different health care centres. The aggregated number of diarrhoea episodes per municipality was used to estimate the incidence of this disease.

\section{Geostatistical and cartographic data analyses}

Data were geo-referenced at the lowest possible common unit. Descriptive statistical analysis for different frequencies was applied, enabling the production of graphs and tables on the water supply modes, water quality and the incidence of diarrhoea. For statistical analysis, we used SPSS version 18 (Chicago, USA). Cross-analyses between socio-environmental, microbiological and epidemiological variables were carried out to identify correlations (intermediate correlation matrix). Principal component analysis (PCA) was used to investigate relations between supply modes, water quality and diarrhoeal morbidity.

Data were geographically referenced and cartographically represented to allow for an analytical linkage of socio-environmental (e.g. supply modes), microbiological (e.g. water quality) and epidemiological (e.g. diarrhoeal disease) information, using modern cartographic methods. Mapping was based on model output data, using ArcGIS version 10. Geo-statistical data were complemented by digital map data to quantitatively investigate the linkage between risk factors and diarrhoeal incidence. The first geostatistical analysis applied generated a series of surface maps that were re-classified into different classes considering separate independent variables applying the methods of small maps. This approach of spatial analysis produces surface maps containing information on drinking water modes supply and diarrhoeal morbidity, according to spatial gradient evolving from lower to higher levels of spatialised phenomena. Subsequently, we employed a geospatial technique to describe the nature of water supply (e.g. improved or unimproved sources) and water quality (e.g. potable drinking water, contaminated drinking water and highly contaminated drinking water). This information was spatially overlaid and represented as points at the unit of the municipality. Our approach revealed the relationship between the nature of water source and water quality, and points to the spatial magnitude of the vulnerability to water problems. Superposition of two dependent variables on the same map aims to visualise the linkages between modes of water supply and quality of drinking water. Finally, a geospatial approach was employed, overlaying the nature of water source on surface information. The highest value was considered mapping the type of water source, distinguishing between improved and unimproved sources.

\section{Results}

\section{Spatial distribution of modes of water supply}

The Permanent Survey on Living Conditions of Households, carried out in 2008/2009, revealed that $25.6 \%$ of households in Nouakchott had improved sources of water supply (i.e. tap water at home, neighbour tap and public tap). The remaining three quarters of urban dwellers rely on unimproved sources, such as truck water, retailers, tankers or wells without pump. Fig. 1 shows the spatial distribution of the three main improved water sources and two unimproved sources (i.e. tankers and retailers carters), stratified by municipality. 

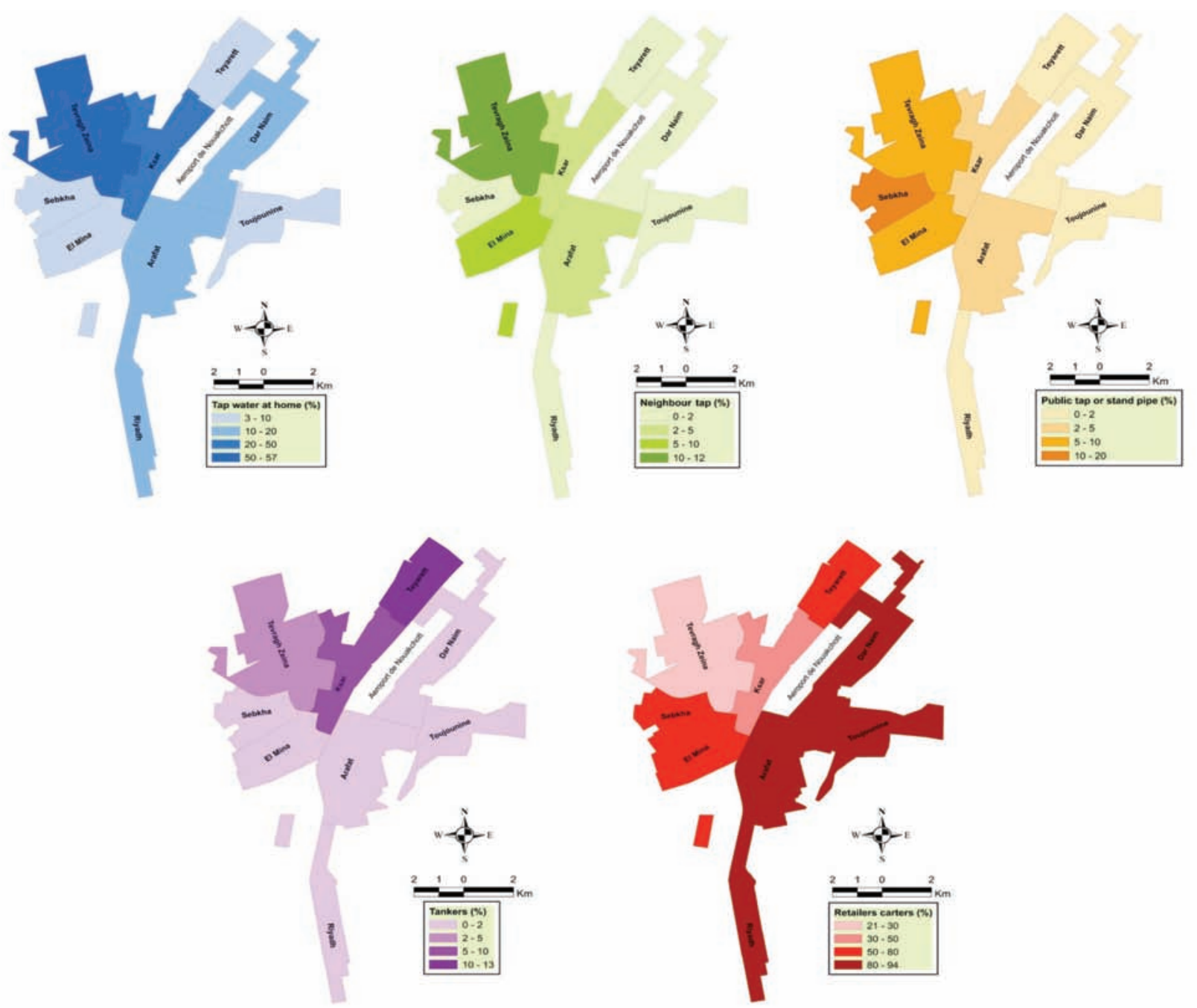

Fig. 1. Different modes of water supply in the nine municipalities of Nouakchott, Mauritania in 2009.

\section{Bacterial analysis}

The analysis of water samples identified faecal contamination through some parts of the water distribution network. Samples from nine water points tested revealed a concentration of $>1$ coliform bacterium per $100 \mathrm{ml}$ of water in three points (two water taps at home and one water tower). In these three water points, between three and 27 coliform bacteria per $100 \mathrm{ml}$ were found. Regarding the water collection points (water basins and springs), bacterial analyses showed that $93 \%$ of the 150 water sources were contaminated by bacteria with an average concentration of between 10 and 80 per $100 \mathrm{ml}$ (Fig. 2a). Only a small number of water points (11 out of $150,7 \%$ ), located in the municipalities of Arafat, El Mina and Dar Naim, were considered as potable. The comparison between different modes of supply showed that the contamination was particularly high in unim- proved sources, while most of the water from private or public taps (improved sources) had a better quality.

Data from epidemiological monitoring revealed the importance of diarrhoeal diseases in Nouakchott. Diarrhoea was the second most frequent cause for medical consultation after acute respiratory tract infection. Overall, $12.8 \%$ of the health care visits were due to diarrhoea. The highest frequency of diarrhoea was reported among children below the age of 5 years $(51.6 \%)$, whereas the frequency in adults was $32.4 \%$ and that in children aged $5-14$ years was $14.1 \%$. The highest prevalence was found in Sebkha (19.1\%), whereas the lowest was revealed in Tevragh Zeina (9.1\%) (Fig. 2b). The uneven distribution of diarrhoeal morbidity mirrors that of the distribution mode (and quality) of water, since the prevalence was found to be higher in areas characterised by unimproved sources of supply with the water emanating mainly from predominantly contaminated water points (Fig. 3). The combination of water supply and 

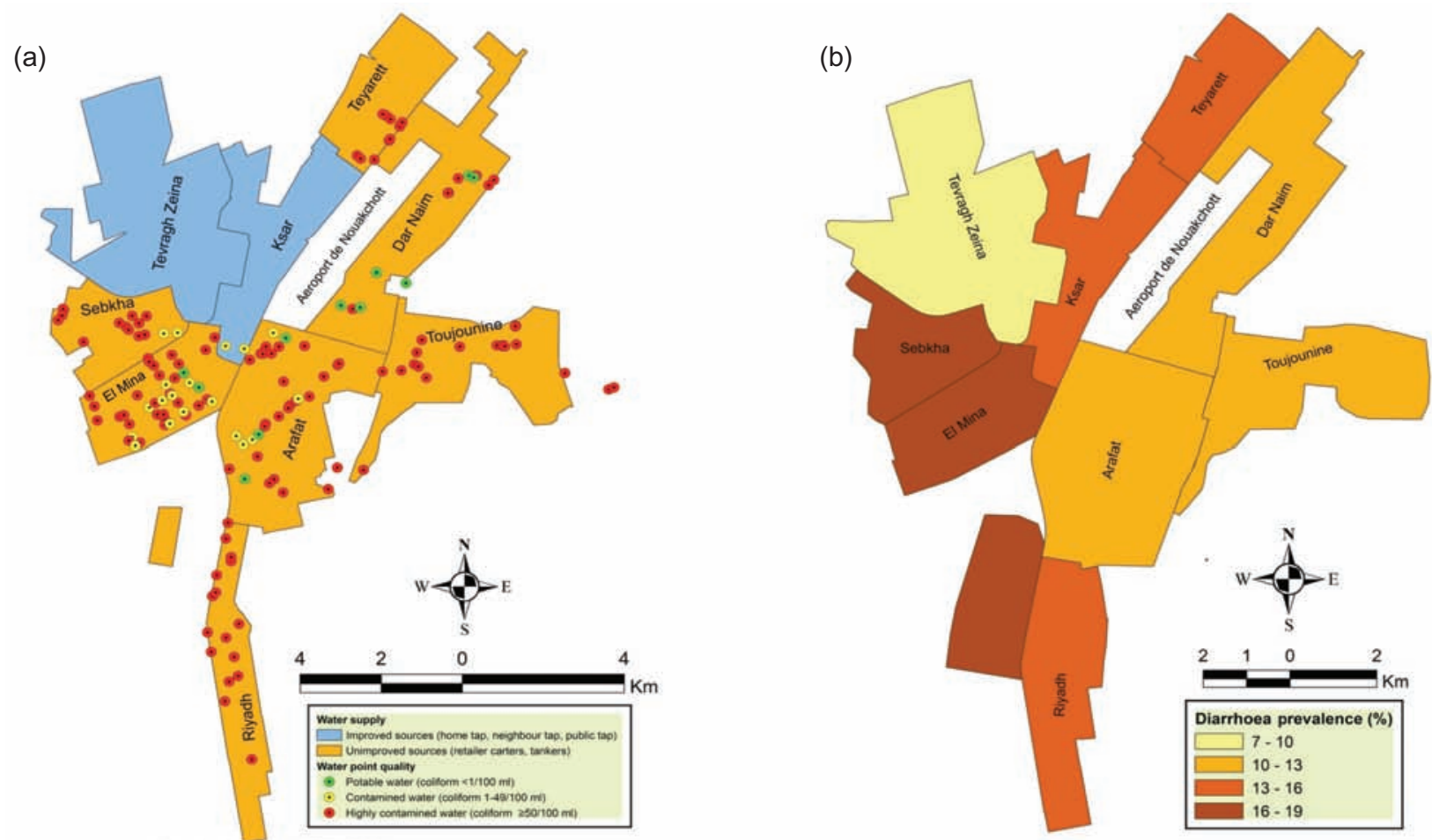

Fig. 2. Water quality, as assessed by bacterial analysis (a) and diarrhoeal prevalence, according to data from health care facilities (b) in the nine municipalities of Nouakchott, Mauritania in 2009.

water quality is closely related to the prevalence of diarrhoeal diseases. The prevalence was particularly high in municipalities with high population densities where households rely on unimproved water sources.

\section{Risk factors for diarrhoea}

Table 1 shows the results of the intermediate correlation analyses. We found that unimproved water sources were strongly correlated with contaminated water (correlation coefficient 0.789), whereas improved water sources were strongly associated with potable water (correlation coefficient 0.788 ).
These correlations are confirmed by PCA that revealed the existence of two segments, F1 and F2, with a significant cumulative variance $(93.9 \%)$. The F1 segment, with a variance of $74.5 \%$, was constituted by the systematic coupling of improved source and potable water, which influences the neighbourhood in a positive direction. The F2 group, on the other hand, with a variance of $19.4 \%$, highlight the close relation between unimproved, contaminated water sources and prevalence of diarrhoea, showing a negative correlation (Fig. 4a). Depending on the type of water access and water quality, significant differences were observed. Inhabitants of municipalities with access to

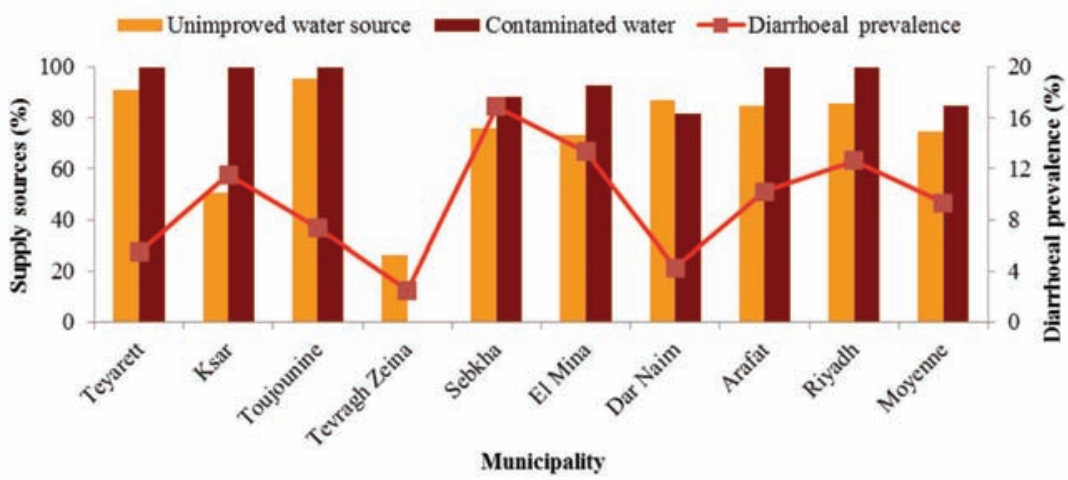

Fig. 3. Association between the frequence of unimproved water sources, the bacterial contamination of water points and the prevalence of diarrhoea at the municipality level in Nouakchott, Mauritania in 2009. 
Table 1. Correlation matrix between observed variables by water quality and diarrhoea in Nouakchott, Mauritania in 2009.

\begin{tabular}{lccccc}
\hline & \multicolumn{4}{c}{ Variable } \\
\cline { 2 - 5 } Variable & $\begin{array}{c}\text { Improved } \\
\text { water source }\end{array}$ & $\begin{array}{c}\text { Potable } \\
\text { water }\end{array}$ & $\begin{array}{c}\text { Unimproved } \\
\text { water source }\end{array}$ & $\begin{array}{c}\text { Contaminated } \\
\text { water }\end{array}$ & $\begin{array}{c}\text { Diarrhoeal } \\
\text { morbidity }\end{array}$ \\
\hline Improved water source & 1.000 & - & - & - & - \\
Potable water & 0.788 & 1.000 & - & - & - \\
Unimproved water source & -1.000 & -0.789 & 1.000 & - & - \\
Contaminated water & -0.788 & -1.000 & 0.789 & 1.000 & - \\
Diarrhoeal morbidity & -0.187 & -0.450 & 0.188 & 0.450 & 1.000 \\
\hline
\end{tabular}

piped water are at a lower risk of diarrhoea than those whose drinking water is obtained from a street dealer or another non-potable source. People whose primary source of drinking water stem from a carter dealer or a water group were at a two-fold higher risk of diarrhoea compared to those with water piped into their homes. Table 2 shows the correlation matrix of the nine municipalities, considering the various variables investigated (socio-environmental, microbiological and epidemiological data). The intermediate correlation matrix between water source, water quality and diarrhoeal morbidity illustrates considerable similarity between seven municipalities that face the same kind of water problems, as showed by the segments $\mathrm{F} 1$ and F2 with a significant cumulative variance (88.9\%) (Fig. 4b).

Analysis of socio-environmental data showed that households with improved water sources were mainly concentrated in the municipalities of Tevragh Zeina $(73.4 \%)$ and Ksar $(49.4 \%)$, while low rates were found in Toujounine $(4.9 \%)$ and Teyarett $(9.5 \%)$ (Figs. 1 and 2a). People with poorer socioeconomic status such as those living in Riyadh, Dar Naim and Teyarett purchase water, which is, on average, 10 times more expensive (UM 1,000 per $\mathrm{m}^{3}$, approximately US\$ 3.7) than those connected to the water network in the municipalities of Tevragh Zeina and Ksar.
Fig. 5 shows the final output from our integrated geographical approach, namely the prevalence of diarrhoea in the nine municipalities of Nouakchott in 2009 , stratified into three age groups.

\section{Discussion}

Potable water is considered an essential component of individual and collective hygiene and close associations have been observed with sanitation (Obrist et al., 2006; Batram and Cairncross, 2010; Hunter et al., 2010). As a result, the influence of water (and sanitation and hygiene) on health is undeniable (Batram and Cairncross, 2010; Freeman et al., 2013). This is especially the case in environments where the rate of connection to public water supply is low and the available quantity of water is subject to practices that degrade the water quality by the introduction of pathogens (Willis et al., 2011). We used an integrated geographical approach, combining socio-environmental, microbiological and epidemiological data, for an in-depth analysis exploring the links between sources of supply, degree of water contamination and extent of diarrhoeal morbidity in Nouakchott to deepen our understanding of the spatial heterogeneity, which might subsequently guide public health interventions (Utzinger et al., 2011a).

Table 2. Correlation matrix between the nine municipalities of Nouakchott, Mauritania in 2009.

\begin{tabular}{|c|c|c|c|c|c|c|c|c|c|}
\hline \multirow[b]{2}{*}{ Municipality } & \multicolumn{9}{|c|}{ Municipality } \\
\hline & Teyarett & Ksar & Tevrag Zeina & Toujounine & Sebkha & El Mina & Dar Naim & Arafat & Riyadh \\
\hline Teyarett & 1.000 & - & - & - & - & - & - & - & - \\
\hline Ksar & 0.810 & 1.000 & - & - & - & - & - & - & - \\
\hline Tevrag Zeina & 0.554 & 0.933 & 1.000 & - & - & - & - & - & - \\
\hline Toujounine & 0.897 & 0.618 & 0.346 & 1.000 & - & - & - & - & - \\
\hline Sebkha & 0.892 & 0.774 & 0.567 & 0.958 & 1.000 & - & - & - & - \\
\hline El Mina & 0.623 & 0.474 & 0.317 & 0.877 & 0.891 & 1.000 & - & - & - \\
\hline Dar Naim & 0.961 & 0.686 & 0.408 & 0.876 & 0.808 & 0.563 & 1.000 & - & - \\
\hline Arafat & 0.961 & 0.749 & 0.494 & 0.979 & 0.966 & 0.804 & 0.931 & 1.000 & - \\
\hline Riyadh & 0.855 & 0.540 & 0.267 & 0.699 & 0.585 & 0.301 & 0.950 & 0.771 & 1.000 \\
\hline
\end{tabular}


A

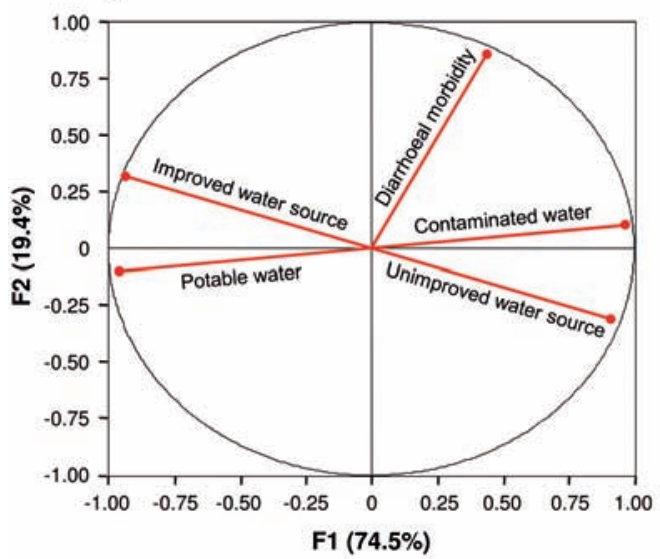

B

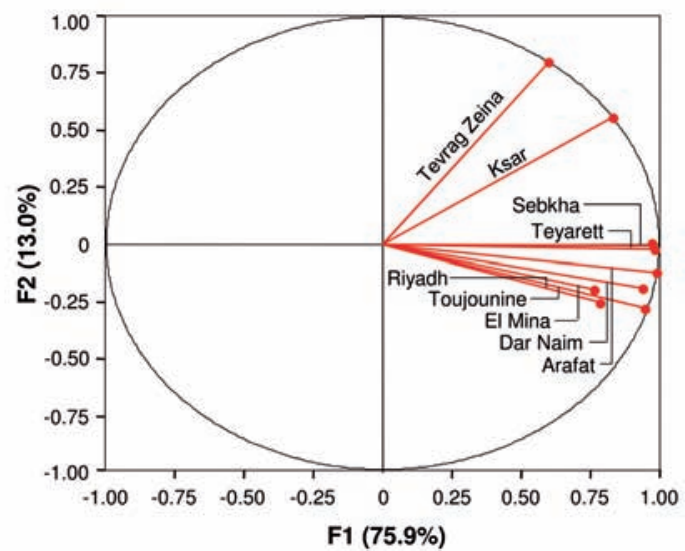

Fig. 4. Projection of correlation matrix between independent and dependent variables pertaining to water quality and diarrhoea in Nouakchott, Mauritania in 2009. (A) Correlation between improved water sources, unimproved water sources and diarrhoea (axes F1 and F2: 93.9\%); (B) correlation stratified by municipality (axes F1 and F2: 88.9\%).

We identified three levels of inequality between households connected to the supply network and those dependent on off-grid water distribution pathways, namely (i) inequality of access (quantity); (ii) unequal prices; and (iii) unequal quality. These sources of differences are the cause of socio-spatial segregation in which one segment of the population with a sufficient amount of water (more than 1001 per person per day) live close to another segment with water stress (about 151 per person per day) who pay a high prize for poor quality water. Such a situation of controversial circumstances, which disproportionately affects populations of the lowest socioeconomic status in marginalised areas leads to attitudes and practices that could further exacerbate the water quality with an increased risk of contamination. On this point, it was shown that household practices related to the conservation of water in containers (e.g. buckets, drums and cans), or handling during transport have a significant effect on its quality (Sy et al., 2010a).

In Nouakchott, as shown through the overlay of different data sources, results revealed the evolution of water quality according to the nature of the sources of supply. The situation appears even more serious given that the results of the bacteriological analysis that identified the presence of faecal coliform bacteria (e.g. Salmonella and Escherichia coli) exceeding the maximum acceptable concentration (WHO, 2006) in some areas of the network and water points in the city. The presence of coliform bacteria in drinking water is a typical sign of faecal contamination arising either from seepage of polluted water into the pipes, or handling of water with insufficient hygiene precautions (Mokofio et al., 1991; Howard et al., 2006). In fact, the detection of faecal coliform bacteria in treated water raises the level of suspicions regarding faecal
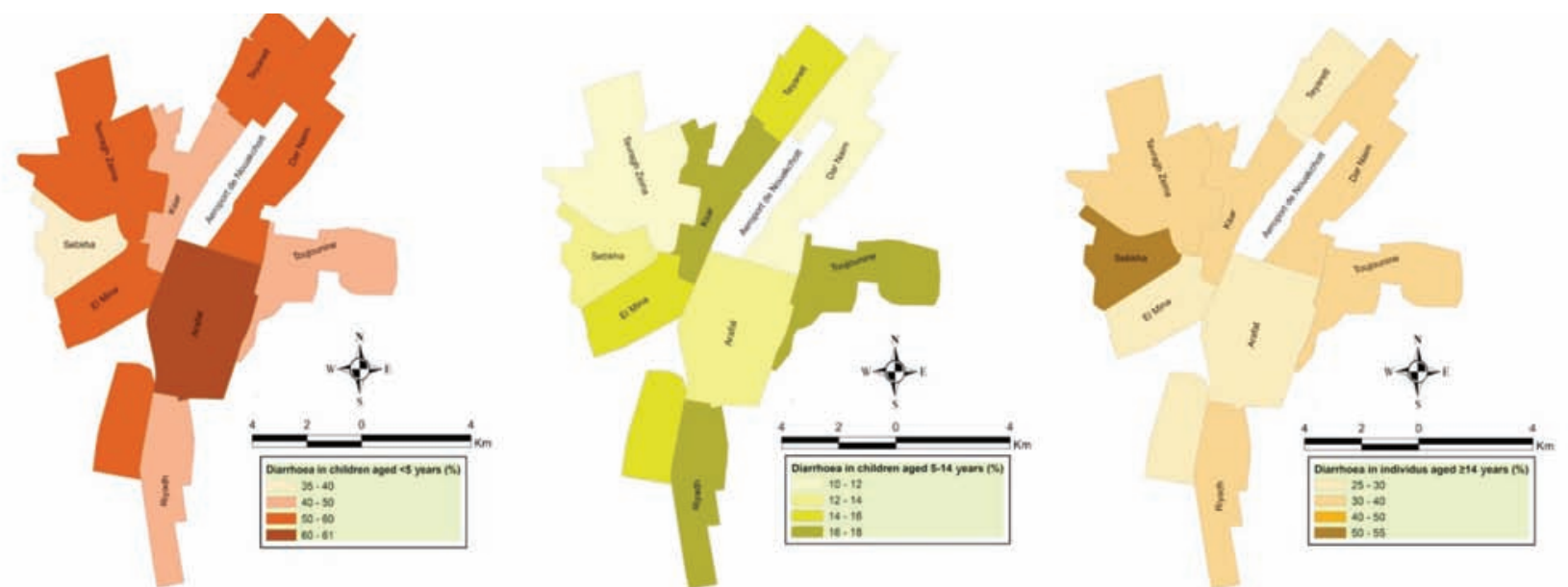

Fig. 5. Prevalence rates of diarrhoeal diseases according to age group and municipalities in Nouakchott, Mauritania in 2009. 
contamination. If water supplied through an existing network is of a good initial quality, contamination occurs after the primary piper, over the course of transport, handling at the water points or during storage. This might be explained by precarious hygienic conditions. However, mostly in the summer months, when water temperatures exceed $15^{\circ} \mathrm{C}$, the proliferation of bacteria is sometimes observed repeatedly, particularly in distribution networks that are not properly maintained (Howard and Bartram, 2005; Clasen and Haller, 2008).

The contamination of water sources (e.g. water basins and springs) could be linked to the absence of proper standards in sanitation in households (lack of sanitation or inappropriate position of latrines). A regulatory distance of $12 \mathrm{~m}$ between septic tanks and a water source is imperative according to guidelines put forward by the World Health Organization (WHO, 2006). However, the results of a recent survey done in Nouakchott (CUN-INRSP, 2009) show that between 200 and 250 water points were located at a distance of less than $12 \mathrm{~m}$ from septic tank. Hence, there is considerable risk of contamination between water points and pit latrines. This issue might be an important underlying reason for the cholera epidemic that occurred in 2005, following intense rains that might have caused infiltration of sewage from septic tanks into drinking water sources. Such observations have also been made in sub-urban areas of other African cities, where toilet facilities consist of latrines whose poor construction standards were not controlled for the most part, and hence waste was directly discharged into the ground, where it could seep into the groundwater (Dieng et al., 1999; Carr and Neary, 2008; Nguendo-Yongsi, 2011).

In developing country cities, the rate of mortality and morbidity due to diseases related to poor water quality is still unacceptably high (Bartram and Cairncross, 2010; Cairncross et al., 2010; Hunter et al., 2010; Murray et al., 2012). This is especially true as the improvement of water quality significantly reduces the transmission of enteric pathogens causing diarrhoea, particularly in infants (Briscoe et al., 1986; UNICEFWHO, 2012). Hence, access to water does not guarantee its quality, which also depends on human practices that are more or less favourable to the introduction of pathogens. For example, the collected water, which is often perceived as safe by households, is not usually subjected to specific treatment even after long storage periods under precarious hygienic conditions (Dos Santos and Legrand, 2007). Contamination risks further aggravate and consumers, especially young chil- dren, are most exposed to diseases, such as gastroenteritis (Nguendo-Yongsi et al., 2008; Sy et al., 2010b; Becker et al., 2013). Thus, the development of diarrhoeal diseases appears to be the product of a complex relationship between supply sources and water quality. The reported morbidity rate of $12.8 \%$, however, is considerably lower compared to a prevalence of $17.2 \%$ observed in a survey in disadvantaged neighbourhoods in 2004 and $18.2 \%$ recorded as a result of a comparative study of two municipalities with different socioeconomic status (Sy et al., 2010a, 2011). Two previous studies implemented in Nouakchott highlight the crucial role of access to water, as well as its quality, on the transmission of diarrhoea. Moreover, the high prevalence of diarrhoea observed in some municipalities could be explained by the lack or complete absence of a source of quantitatively and qualitatively adequate water supply. Of note, morbidity does not evolve according to the deteriorating situation of water (low access and high contamination) in Arafat and Teyarett. In these municipalities, the low use of healthcare and diarrhoeal treatment perhaps explains the low rate of reported diarrhoeal morbidity.

The spatial heterogeneity of diarrhoeal prevalence indicates that health problems are individualised according to municipalities in the same manner that the sources of drinking water supply are specific. Our research shows that areas characterised by high diarrhoeal morbidity are those parts of the city that are most poorly supplied with potable water and where contamination is highest. The correlation matrix showed that this health risk factor is related to the distributed water. However, if the lack of potable water in urban areas creates a specific socio-ecological system, the process is spatially and socially so unequal and differentiated that there is a need to distinguish zones and populations in the urban areas according to their degree of exposure to a particular health risk due to contamination of the supplied water (DorierApprill, 1993; Salem, 1998). Hence, to understand the causes of a disease, recognising that the risk factors are many and varied, it is recommended to adopt a socialecological perspective and consider the disease as the result of interactions between socioeconomic factors, ecological features and health systems issues that operate at specific environmental, spatial and temporal conditions and scales (Sy, 2006; Nguendo-Yongsi et al., 2008; Utzinger et al., 2011b). As shown in our studies, the available data are not all too much spatially disaggregated, and hence, additional household surveys are required to draw meaningful conclusions and policy recommendations. 


\section{Conclusions}

Water supply and its association to social practices are issues characterising the situation of access to potable water, as shown in the current investigation in Nouakchott. Hence, safe-keeping of the potable nature of drinking water is a major challenge in a context where contamination of a supply source is common. By producing a series of small maps illustrating the evolution of the observed phenomenon and maps overlaying different related information, the contribution of geospatial techniques used is undeniable as they improve the state of scientific knowledge and tools of decision support, especially in the field of public health. The predominance of unimproved sources of drinking water as well as increased risks of contamination offer favourable conditions for the circulation of pathogens in urban settlements of Nouakchott. Analysis revealed a poor microbiological quality of water that exposes consumers to health risks. Our integrated geographical approach to diarrhoeal diseases at the unit of the municipality presents many aspects of African cities growth, their relationship with chronic diseases of poverty and its consequences on urban dweller's health and wellbeing. The medical literature links the indemnity of this pathology to precarious living conditions of households, strongly governed by the lack of access to potable water. Thus, it is important not only to increase the monitoring of supply sources, but also to promote health education in order to prevent water pollution. In this respect, interventions in response to the cholera epidemic that occurred in 2005 to improve the water quality by reducing the risk of contamination of water sources in the sub-urban areas of Nouakchott with support from the Spanish Cooperation are initiatives that should be further promoted. Actions based on awareness, management of water sources and treatment before consumption are some measures to apply in order to protect users to potential health risks.

\section{Acknowledgements}

This study received financial support from the Swiss National Centre of Competence in Research (NCCR) NorthSouth: Research Partnerships for Mitigating Syndromes of Global Change, co-funded by the Swiss National Science Foundation, the Swiss Agency for Development and Cooperation, and the participating institutions, namely the National Institute of Research for Public Health and Nouakchott Urban Community.

\section{References}

Bartram J, Cairncross S, 2010. Hygiene, sanitation, and water: forgotten foundations of health. PLoS Med 7, e1000367.

Becker SL, Vogt J, Knopp S, Panning M, Warhurst DC, Polman K, Marti H, von Müller L, Yansouni CP, Jacobs J et al., 2013. Persistent digestive disorders in the tropics: causative infectious pathogens and reference diagnostic tests. BMC Infect Dis $13,37$.

Bergquist R, Rinaldi L, 2010. Health research based on geospatial tools: a timely approach in a changing environment. J Helminthol 84, 1-11.

Briscoe J, Feachem RG, Mujibur Rahaman M, 1986. Evaluating health impact: water supply, sanitation, and hygiene education. UNICEF, ICDDR_B, IDRC. Ottawa: International Development Research Centre.

Cairncross S, Bartram J, Cumming O, Brocklehurst C, 2010. Hygiene, sanitation, and water: what needs to be done? PLoS Med 7, e1000365.

Carr GM, Neary JP, 2008. Water quality for ecosystem and human health. United Nations Environment Programme (UNEP), Global Environment Monitoring System/Water Programme, $2^{\text {nd }}$ ed., p. 130.

Clasen TF, Haller L, 2008. Water quality interventions to prevent diarrhoea: cost and cost effectiveness. Geneva: World Health Organization, p. 40.

CUN-INRSP, 2009. Evaluation de la qualité physico-chimique et bactériologique de l'eau des différents circuits d'approvisionnement à Nouakchott (Mauritanie). Rapport d'étude. Nouakchott: Communauté Urbaine de Nouakchott (CUN) and Institut National de Recherche en Santé Publique (INRSP), p. 25.

Dieng Y, Tandia AA, Wane AT, Gaye O, Diop ES, Diallo S, 1999. Les parasitoses intestinales chez les habitants d'une zone péri-urbaine à nappe phréatique polluée par les nitrates d'origine fécale. Cahiers-Santé 9, 351-356.

Dorier-Apprill E, 1993. Environnement et santé à Brazzaville: de l'écologie à la géographie sociale. $\mathrm{PhD}$ thesis, Université de Paris 10, p. 668.

Dos Santos S, Legrand TK, 2007. Accès à l'eau et mortalité des enfants à Ouagadougou (Burkina Faso). Environ Risque Sante 6, 365-371.

Fewtrell L, Kaufmann RB, Kay D, Enanoria W, Haller L. Colford JM Jr, 2005. Water, sanitation and hygiene interventions to reduce diarrhoea in less developed countries: a systematic review and meta-analysis. Lancet Infect Dis 5, 42-52.

Freeman MC, Ogden S, Jacobson J, Abbott D, Addiss DG, Amnie AG, Beckwith C, Cairncross S, Callejas R, Colford JM Jr et al., 2013. Integration of water, sanitation, and hygiene for the prevention and control of neglected tropical diseases: a rationale for inter-sectoral collaboration. PLoS Negl Trop Dis 7, e2439. 
Gagneux S, Schneider C, Odermatt P, Cissé G, Tanner M, 1999. La diarrhée chez les agriculteurs urbains de Nouakchott en Mauritanie. Med Trop 59, 253-259.

Howard G, Bartram J, 2005. Effective water supply surveillance in urban areas of developing countries. J Water Health 3, 3143.

Howard G, Pedley S, Tibatemwa S, 2006. Quantitative bacterial risk assessment to estimate health risks attributable to water supply: can the technique be applied in developing countries with limited data? J Water Health 4, 49-65.

Hunter PR, MacDonald AM, Carter RC, 2010. Water supply and health. PLoS Med 7, e1000361.

Kjellstrom T, Mercado S, Sattherthwaite D, McGranahan G, Friel S, Havemann K, 2007. Our cities, our health, our future: acting on social determinants for health equity in urban settings. Report to the WHO commission on social determinants of health from the knowledge network on urban settings. Kobe, p. 70.

Lozano R, Naghavi M, Foreman K, Lim S, Shibuya K, Aboyans V, Abraham J, Adair T, Aggarwal R, Ahn SY et al., 2012. Global and regional mortality from 235 causes of death for 20 age groups in 1990 and 2010: a systematic analysis for the Global Burden of Disease Study 2010. Lancet 380, 2095 2128.

Mokofio F, Renaudet J, Opandy C, Bastard G, Abeye J, Yete ML, Touabe J, Gondao L, Vohito JA, 1991. Qualité bactériologique de l'eau des puits, des sources et des forages dans la ville de Bangui: premiers résultats et perspectives. Med Afr Noire 38, 775-778.

Murray CJL, Vos T, Lozano R, Naghavi M, Flaxman AD, Michaud C, Ezzati M, Shibuya K, Salomon JA, Abdalla S et al., 2012. Disability-adjusted life years (DALYs) for 291 diseases and injuries in 21 regions, 1990-2010: a systematic analysis for the Global Burden of Disease Study 2010. Lancet, 380, 2197-2223.

Nguendo-Yongsi B, Salem G, Bruneau JC, 2008. Epidémiologique géographique des maladies diarrhéiques à Yaoundé (Cameroun). M@ppemonde 89, 17.

Nguendo-Yongsi HB, 2011. Microbiological evaluation of drinking water in sub-Saharian urban community (Yaoundé, Cameroon). Am J Biochem Mol Biol 1, 68-81.

Obrist B, Cissé G, Koné B, Dongo K, Granado S, Tanner M, 2006. Interconnected slums: water, sanitation and health in Abidjan, Côte d'Ivoire. Eur J Dev Res 18, 319-336.

ONS, 2007. Enquête nationale à indicateurs multiples (MICS). Nouakchott: Office National de la Statistique, p. 61.

ONS, 2009. Profil de la pauvreté en Mauritanie. Rapport final de l'enquête permanente sur les conditions de vie (EPVC). Nouakchott: Office National de la Statistique, p. 173.

Ould Samba D, Perrin N, 2008. Répartition des volumes d'eau à Nouakchott, Mauritanie. Rapport d'enquête. Nouakchott: GRET, CUN, Île de France, p. 32.
Prüss-Üstün A, Bos R, Gore F, Bartram J, 2008. Safer water, better health: costs, benefits and sustainability of interventions to protect and promote health. Geneva: World Health Organization, p. 60.

Salem G, 1998. La santé dans la ville. Géographie d'un espace dense: Pikine (Sénégal). Paris: Editions Karthala-ORSTOM, p. 360.

Sy I, 2006. La gestion de la salubrité à Rufisque. Enjeux sanitaires et pratiques urbaines. $\mathrm{PhD}$ thesis, Université Louis Pasteur de Strasbourg, p. 563.

Sy I, Handschumacher P, Wyss K, Piermay JL, Lô B, Cissé G, Tanner M, 2010b. Variabilité des maladies diarrhéiques chez les enfants de moins de 5 ans en milieu urbain: l'exemple de Rufisque au Sénégal. Med Trop 70, 57-62.

Sy I, Keita M, Lô B, Tanner M, Cissé G, 2010a. Gestion des déchets urbains et risques sanitaires: approche comparative entre deux communes de Nouakchott (Mauritanie). Actes du Colloque Eau, Déchets et Développement Durable, 28-31 March 2010. Alexandrie, p. 343-352.

Sy I, Koita M, Traoré D, Keita M, Lô B, Tanner M, Cissé G, 2011. Vulnérabilité sanitaire et environnementale dans les quartiers défavorisés de Nouakchott (Mauritanie): analyse des conditions d'émergence et de développement de maladies en milieu urbain sahélien. VertigO 11, 17.

Tessier S, 1991. Les maladies de l'enfant liées à l'eau en milieu urbain. Colloque pluridisciplinaire géographie-médecine sur l'eau et la santé en Afrique tropicale. Limoges, PULIM 63-72. Tumwine JK, Thompson J, Katua-Katua M, Muiwajuzi M, Johnson Porras I, 2002. Diarrhea and effects of different water sources, sanitation and hygiene behavior in East Africa. Trop Med Int Health 7, 750-756.

UNICEF-WHO, 2009. Diarrhoea: why children are still dying and what can be done. Geneva: United Nations Children's Fund and World Health Organization, p. 68.

UNICEF-WHO, 2012. Progress on drinking water and sanitation. Update 2012, Joint Monitoring Programme (JMP). Geneva: United Nations Children's Fund and World Health Organization, p. 68.

Utzinger J, N'Goran EK, Caffrey CR, Keiser J, 2011b. From innovation to application: social-ecological context, diagnostics, drugs and integrated control of schistosomiasis. Acta Trop 120, S121-S137.

Utzinger J, Rinaldi L, Malone JB, Krauth SJ, Kristensen TK, Cringoli G, Bergquist R, 2011a. Geospatial Health: the first five years. Geospat Health 6, 137-154.

Vaguet A, 1986. Eau, ville et maladie. Le choléra dans une métropole indienne: Hyderabab. Atelier de Géographie de la Santé, GEOS n. 4, Université Paul Valery, Montpellier, p. 28. WHO, 2006. Guidelines for drinking-water quality. Vol. 1, Recommendations. $3^{\text {rd }}$ ed. Geneva: World Health Organization. WHO-UN-Habitat, 2010. La face cachée des villes: mettre au jour et vaincre les inégalités de santé en milieu 
urbain. Geneva: World Health Organization, United Nations and Habitat, p. 145.

Willis RM, Stewart RA, Panuwatwanich K, Williams PR,
Hollingsworth AL, 2011. Quantifying the influence of environmental and water conservation attitudes on household end use water consumption. J Environ Manage 92, 1-14. 